\title{
Growth, morphological traits and mycorrhizal colonization of fine roots respond differently to nitrogen addition in a slash pine plantation in subtropical China
}

\author{
Liang Kou • Dali Guo • Hao Yang • Wenlong Gao • \\ Shenggong Li
}

Received: 22 July 2014 / Accepted: 16 February 2015 / Published online: 28 February 2015

(C) Springer International Publishing Switzerland 2015

\begin{abstract}
Background and aims Growth, morphological traits, and mycorrhizal colonization of fine roots show high degree of plasticity in response to changes in nutrient availability, causing shifts in root nutrient-foraging strategy. However, little is known about how this plasticity associated with root branching orders respond to atmospheric nitrogen $(\mathrm{N})$ deposition in subtropical coniferous forests.

Methods We used soil block sampling method to examine the responses of six key root functional parameters (including three morphological traits (specific root length (SRL), root tissue density (RTD), and root diameter), two growth indices (total root length (TRL) and biomass) on an areal basis across five root orders, and ectomycorrhizal (EM) tip colonization) to different
\end{abstract}

Responsible Editor: Harry Olde Venterink.

Electronic supplementary material The online version of this article (doi:10.1007/s11104-015-2420-x) contains supplementary material, which is available to authorized users.

L. Kou $\cdot$ D. Guo $\cdot$ H. Yang $\cdot$ W. Gao $\cdot$ S. Li $(\bowtie)$

Key Laboratory of Ecosystem Network Observation and

Modeling, Institute of Geographic Sciences and Natural

Resources Research, Chinese Academy of Sciences,

Beijing 100101, China

e-mail: lisg@igsnrr.ac.cn

L. Kou $\cdot$ W. Gao

University of Chinese Academy of Sciences, Beijing 100049, China doses and species of $\mathrm{N}$ addition in a slash pine (Pinus elliottii) plantation in subtropical China.

Results TRL, root biomass in all root orders, and EM tip colonization increased significantly with $\mathrm{N}$ addition. However, SRL, RTD, and root diameter did not change in any root orders. In comparison to low doses of $\mathrm{N}$ input, high doses of $\mathrm{N}$ input exerted greater effects on lower-order roots. In regard to species of $\mathrm{N}$ added, stronger responses in lower-order roots were observed under ammonium-based than nitrated-based $\mathrm{N}$ input. Foliar P content was significantly decreased and stoichiometric $\mathrm{N}: \mathrm{P}$ ratio was markedly increased in response to high dose of ammonium-based $\mathrm{N}$ input.

Conclusions Fine root growth and EM tip colonization displayed higher degree of plasticity than morphological traits in response to $\mathrm{N}$ addition. The plastic responses were not root-order dependent, but dependent on both $\mathrm{N}$ dose and species, especially for ephemeral lower-order roots that are mostly like to be the main nutrient acquisition structures. Our results imply that while N limitation was alleviated by exogenous $\mathrm{N}$ input, $\mathrm{P}$ limitation may persist or even be exacerbated, thus causing an increase of absorptive root length, biomass, and dependence on ectomycorrhizae for nutrient acquisition in subtropical slash pine plantation forests.

Keywords Ectomycorrhizal tip colonization .

Fine root growth · Morphological traits .

Nitrogen deposition $\cdot$ Root branching order .

Stoichiometric ratio 


\section{Introduction}

Fine roots and associated mycorrhizal fungi are the primary structures for resource uptake in plants, and have evolved various types of plasticity in resource foraging (e.g., morphological, physiological, and mycorrhizal plasticity) in response to diverse environmental conditions (Hodge 2006; Meier and Leuschner 2008). For instance, plants may adjust and optimize resource foraging strategy by modifying fine root growth (total root length (TRL) and biomass) (Ostonen et al. 2011), morphological traits (e.g., individual root length, root diameter, specific root length (SRL), root tissue density (RTD)) (Wang et al. 2013) and/or physiological traits (nutrient uptake kinetics and nutrient transport) (Mou et al. 2013). In addition, through the symbiotic association between roots and fungi, mycorrhizae expand the capacity of plants to explore for mineral nutrients, especially immobile nutrients (e.g., phosphorus (P), copper, and zinc) by enlarging the volume of soil for uptake, accelerating the movement of $\mathrm{P}$ into mycorrhizal hyphae, and increasing the solubility of soil P (Bolan 1991; Bünemann et al. 2010). Whereas these plasticities in plant roots are generally well-recognized, our specific knowledge on how fine root functional parameters (growth, morphological traits, and mycorrhizal colonization) respond to nitrogen $(\mathrm{N})$ deposition remains rudimentary (Ostonen et al. 2011).

Fine root functional parameters respond differently to changes in availability and form of soil nutrients due to anthropogenic $\mathrm{N}$ deposition or experimental nutrient addition (Lima et al. 2010; Wang et al. 2013; Leuschner et al. 2013). It has been observed that plants may increase fine root growth and/or improve resource foraging efficiency through mycorrhizal symbiosis, when soil nutrients are deficient (Lõhmus et al. 2006; Ostonen et al. 2011). Thus, fine root biomass and length may decrease when soil nutrients become abundant (Wang et al. 2013). Additionally, fine root parameters are often differentially responsive to different forms (e.g., $\mathrm{NO}_{3}{ }^{-}$versus $\mathrm{NH}_{4}{ }^{+}$) and types of nutrients (e.g., $\mathrm{N}$ versus P) (Linkohr et al. 2002; Lima et al. 2010). Several lines of evidence have indicated that $\mathrm{NH}_{4}{ }^{+}$ mainly triggers the initiation of fine roots (e.g., root number and density), whereas $\mathrm{NO}_{3}{ }^{-}$is prone to stimulate the elongation of fine roots (Zhang and
Forde 1998; Lima et al. 2010). Likewise, a metaanalysis of mycorrhizal responses to nutrient fertilization indicates that mycorrhizal colonization rates were negatively related to $\mathrm{P}$ availability, but the response to $\mathrm{N}$ availability was inconsistent (Treseder 2004).

Anthropogenic $\mathrm{N}$ deposition has doubled the input of reactive N (Galloway et al. 2008) which is quantitatively and functionally the most important nutrient for plants and microbes (Noguchi et al. 2013). However, as $\mathrm{N}$ deposition rate persistently exceeds $\mathrm{N}$ demand of plants and microbes, ' $\mathrm{N}$ saturation' may occur with a suite of negative effects, such as soil acidification, loss of soil cations, and shift from $\mathrm{N}$ to $\mathrm{P}$ limitation or further $\mathrm{P}$ and $\mathrm{N}$ colimitation (Aber et al. 1989; Matson et al. 1999; Braun et al. 2010; Cairney 2011), all of which will influence the fine root deployment, growth, and traits associated with nutrient foraging. Research on the responses of fine root growth, morphological traits, and mycorrhizal colonization to $\mathrm{N}$ addition has long been focused on N-limited forests, whereas to our knowledge such responses of the fine roots remain lacking or unclear for tropical and subtropical forests where plant growth may be limited by other nutrients (e.g., P and potassium). Given the escalated $\mathrm{N}$ deposition in tropical and subtropical zones, knowing about how fine root growth and traits intimately related to nutrient-foraging respond to $\mathrm{N}$ deposition in these forests will provide significant insights into mechanisms underlying adaptation of plants to changing environment.

In the present study, we investigated the key root morphological traits (root diameter, SRL, and RTD), root growth (TRL and root biomass), and EM tip colonization of slash pine (Pinus elliottii) plantation in subtropical China. Recent progress on root branching structures revealed that the hierarchical fine root system could be further partitioned into two modules (Xia et al. 2010). Lower-order roots encompassing the most distal two or three orders are functionally responsible for absorption of resources, lignified higher-order roots are primarily endowed with transport and structural functions (Guo et al. 2008, 2013; Rewald et al. 2011). Hence, all root parameters in this study were quantified based on the root branching criteria proposed by Pregitzer et al. (2002) to reduce the structural complexity within fine root system. In an effort to simulate chronic atmospheric wet $\mathrm{N}$ deposition, different doses 
and species of inorganic $\mathrm{N}$ fertilizers were applied on May 2012. We hypothesized that: (i) fine root growth, morphological traits, and EM tip colonization would respond differentially to $\mathrm{N}$ addition since they generally show different degrees of plasticity or phylogenetic conservatism in response to changes in soil nutrient availability; and (ii) the responses of fine root parameters to $\mathrm{N}$ addition would be both dependent on the dose and species of $\mathrm{N}$ added, since plants are commonly preferential for inorganic $\mathrm{N}$ species and responsive to doses of $\mathrm{N}$ added in terms of demand.

\section{Materials and methods}

Site description and experimental design

In November 2011, the chronic N-fertilization experiment was conducted in a 28 -year-old slash pine (P. elliottii) plantation at Qianyanzhou (QYZ) Experimental Station of Red Soil and Hilly Land, Chinese Academy of Sciences (CAS), Jiangxi province, south China (2644'29.1" N, 11503'29.2" E, $102 \mathrm{~m}$ a.s.1.). The study area has a subtropical monsoon climate with mean annual temperature and precipitation of $17.9^{\circ} \mathrm{C}$ and $1475 \mathrm{~mm}$, respectively (Wen et al. 2010). Stand density at the study site is ca. 833 stems ha ${ }^{-1}$. Mean diameter at breast height (DBH) and mean height of the trees are $20.9 \mathrm{~cm}$ and $17.5 \mathrm{~m}$, respectively. Referring to US soil taxonomy, the soil weathered from red sandstone and mud stone is classified to Typical Dystrudepts Udepts Inceptisols. The zonal vegetation was restored from 1985 by planting slash pine (P. elliottii), Masson pine (P. massoniana) and Chinese fir (Cunninghamia lanceolata). The understory vegetation is dominated by Woodwardia japonica, Loropetalum chinense, and Dicranopteris dichotoma (Wang et al. 2012).

Briefly, a randomized complete block design with three replicates was employed. Each block was divided into five $20 \times 20 \mathrm{~m}$ plots with the buffer zone between any two plots more than $10 \mathrm{~m}$. The slope angle was consistently less than $15^{\circ}$. Within each block, one plot at random served as control receiving ambient $\mathrm{N}$ deposition (approximately $10 \mathrm{~kg} \mathrm{~N}^{-1} \mathrm{yr}^{-1}$ ) (Zhan et al. 2014), and the remaining four plots received ambient $\mathrm{N}$ deposition plus randomly assigned chronic atmospheric $\mathrm{N}$ deposition (40 vs. $120 \mathrm{~kg} \mathrm{~N}$ ha $^{-1} \mathrm{yr}^{-1} \mathrm{NH}_{4} \mathrm{Cl}$ and 40 vs. $120 \mathrm{~kg} \mathrm{~N}^{-1} \mathrm{yr}^{-1} \mathrm{NaNO}_{3}$, respectively.).
Fertilizers were fully dissolved in $30 \mathrm{~L}$ tap water and evenly sprayed in $\mathrm{N}$ addition plots once per month. The control plots were supplied with equivalent amount of tap water to reduce the influence of additional water input. The $\mathrm{N}$ addition started on May 1st, 2012 and proceeded at a month interval on non-rainy days.

\section{Root sampling, processing and dissection}

In late September 2013, P. elliottii roots were excavated referring to the approach in Guo et al. (2004). In order to obtain intact fine root segments, three locations within each plot were randomly chosen and then $30 \mathrm{~cm}$ (length) $\times 20 \mathrm{~cm}$ (width) $\times 10 \mathrm{~cm}($ depth $)$ soil blocks were cut using a machete after clearing away floor litters and gently removed using a shovel. The harvested soil blocks (nine for each treatment) were immediately placed in a plastic bag with ice as a cooler and transported to the laboratory within hours and frozen for subsequent processing.

In the laboratory, the soil blocks were gently loosened by hands to separate roots from the soil. P. elliottii roots are easily distinguished from neighbor roots (Latin names for neighbor species are shown in Table S1 of online resource 1), due to their distinct appearance (e.g., dark-red epidermis of woody roots, dichotomously branched distal roots, and frequently ectomycorrhizal tips). Once separated, large intact $P$. elliottii roots were carefully removed using fine forceps and placed in deionized water $\left(1{ }^{\circ} \mathrm{C}\right)$ to clean off the adhering soil and organic matter particles. To avoid the underestimate of root growth, the remainder of each soil block was sieved $(2 \mathrm{~mm})$ to recover residual root segments and neighbor roots. In this study, $P$. elliottii roots recycled in the process above were few (less than $5 \%$ of total biomass) and consistently higher-order roots (e.g., the 4th and 5th orders), which had abscised from the root system they lived on during the sampling. Therefore, their branching order could only be designated through a diameter comparison with order-determined roots.

In this study, dead roots were excluded based on a suite of characteristics including color, resilience, and toughness. The clean alive intact roots were hierarchically dissected into branch orders by fine forceps following the protocol described by Pregitzer et al. (2002). The most distal roots were defined as the first order roots, two first order roots derived from the second order roots, etc. Although some of soil blocks included the sixth- or even higher-order roots, only the first five 
orders were taken into account in root parameter analysis to guarantee data consistency.

Root morphology, growth and EM tip colonization assessment

The order-specific roots were scanned at a resolution of 400 dpi (Epson Expression 10000XL scanner), and background impurities were removed from each image using Adobe Photoshop version 8.0 LE (Adobe Systems). TRL and root morphological traits were quantified by analyzing scanned images with WinRHIZO Arabidopsis version 2012b (Regents Instruments Inc., Quebec Canada). Once scanned, roots were oven-dried $\left(60{ }^{\circ} \mathrm{C}\right.$, for $\left.48 \mathrm{~h}\right)$ and weighed. TRL and average diameter were automatically calculated and biomass-related parameters (i.e., SRL and RTD) were calculated by dividing root biomass by root length and root volume, respectively.

Additional P. elliottii roots consisting of the first five branch orders were sampled in each plot for the assessment of EM tip colonization (i.e., the 1st order). Soil and organic particles were gently removed by forceps in deionized water $\left(1^{\circ} \mathrm{C}\right)$, and instantly fixed in formalinacetic acid-alcohol (FAA). For each sample, root tips (about 100-150) were randomly excised from the different parts of the root systems. The number of root tips colonized by fungi were viewed and determined under a dissecting microscope at $20 \times$ magnification based on the macroscopic features, such as presence of yellowbrown to golden-brown swollen mantle. The EM tip colonization rate was calculated as: EM tip colonization $(\%)=\mathrm{EM}$ root tips $\times 100 /(\mathrm{EM}$ root tips + vital non-EM root tips) (Danielsen et al. 2013; Teste et al. 2014).

Soil and needle foliage sampling and chemical analyses

The sieved ( $2 \mathrm{~mm}$ sieve) root-free soil from three soil blocks in each plot was evenly mixed as one composite sample (approximately $200 \mathrm{~g}$ ). Approximately $30 \mathrm{~g}$ subsample was dried in an oven at $105^{\circ} \mathrm{C}$ to determine the soil water content, and approximately $13-15 \mathrm{~g}$ soil was used for the extraction $\left(2 \mathrm{~mol} \mathrm{~L}^{-1} \mathrm{KCl}, 50 \mathrm{ml}\right)$ of mineral soil $\mathrm{N}\left(\mathrm{NH}_{4}{ }^{+}-\mathrm{N}\right.$ and $\left.\mathrm{NO}_{3}{ }^{-}-\mathrm{N}\right)$. The concentrations of $\mathrm{NH}_{4}{ }^{+}$and $\mathrm{NO}_{3}{ }^{-}$were determined with a Flow Auto Analyzer (Bran Luebbe, Germany). Soil pH was measured at a soil: water ratio of 1:2.5 $(w / v)$. Air-dried soil $(10 \mathrm{~g})$ was added to deionized water $\left(25 \mathrm{ml}, 1{ }^{\circ} \mathrm{C}\right)$ and shaken together for $1 \mathrm{~min}$. The $\mathrm{pH}$ was determined after 30 min with a $\mathrm{pH}$ meter (Mettler Toledo, Switzerland).

In late September 2013, we randomly selected three healthy $P$. elliottii trees within the center of each plot and collected their current-year needles using a tall tree trimmer with a bamboo pole. These three foliage samples were evenly mixed to yield one composite sample (approximately $300 \mathrm{~g}$ ). Fresh needle foliage samples were first sterilized $\left(105{ }^{\circ} \mathrm{C}\right.$, for $\left.30 \mathrm{~min}\right)$, and then oven-dried $\left(60{ }^{\circ} \mathrm{C}\right.$, for $\left.48 \mathrm{~h}\right)$ to a constant weight. All the samples were ground using a Restch MM400 mixer mill (Retsch GmbH, Haan, Germany) prior to determining the content of $\mathrm{C}$ and $\mathrm{N}$ using a Vario MAX elemental analyzer (Elementar, Germany), and the content of $\mathrm{P}$ using continuous-flow autoanalyzer (Autoanalyzer 3, Bran and Luebbe, Germany).

\section{Statistical analyses}

All statistical analyses were performed using the SPSS software version 18.0. Two-way ANOVA was used to test effects of $\mathrm{N}$ dose, $\mathrm{N}$ species, and their interactions on fine root growth and morphological traits across root orders and EM tip colonization. One-way ANOVA was used to test treatment effects on soil chemical properties and foliar $\mathrm{C}, \mathrm{N}$, and $\mathrm{P}$ contents. Where required, data were arctan-transformed or $\log _{10}$-transformed to meet assumptions of normality and homogeneity of variance. Significant differences between means were compared using Tukey's test. Linear regression analysis was carried out to determine the relationships between fine root growth (TRL and root biomass), EM tip colonization and foliar chemistry ( $\mathrm{N}$ and $\mathrm{P}$ contents and stoichiometric $\mathrm{N}: \mathrm{P}$ ratio). All statistical graphics were drawn using SigmaPlot software version 12.0.

\section{Results}

Variations of fine root functional parameters in control plots

The key root functional parameters of $P$. elliottii in the control plots varied markedly among root orders. TRL declined with increasing root order, ranging from $103.7 \mathrm{~m} \mathrm{~m}^{-2}$ in the first order to $8.0 \mathrm{~m} \mathrm{~m}^{-2}$ in the fifth order (Table 1). Root biomass increased irregularly with ascending root order, with the lowest value occurring in the second order and the highest value occurring in the 
Table 1 Key root parameters associated with nutrient foraging of Pinus elliottii at $0-10 \mathrm{~cm}$ soil depth in control plots

\begin{tabular}{|c|c|c|c|c|c|c|}
\hline Root order & $\operatorname{TRL}\left(\mathrm{m} \mathrm{m}^{-2}\right)$ & Biomass $\left(\mathrm{g} \mathrm{m}^{-2}\right)$ & $\operatorname{SRL}\left(\mathrm{m} \mathrm{g}^{-1}\right)$ & Diameter (mm) & $\operatorname{RTD}\left(\mathrm{g} \mathrm{cm}^{-3}\right)$ & EM tip colonization $(\%)$ \\
\hline $1 \mathrm{st}$ & $\begin{array}{l}103.7^{\mathrm{a}} \\
(17.4)\end{array}$ & $\begin{array}{l}2.2^{\mathrm{b}} \\
(0.4)\end{array}$ & $\begin{array}{l}48.2^{\mathrm{a}} \\
(3.0)\end{array}$ & $\begin{array}{l}0.31^{\mathrm{d}} \\
(0.01)\end{array}$ & $\begin{array}{l}0.28^{\mathrm{b}} \\
(0.00)\end{array}$ & $71 \%$ \\
\hline $2 \mathrm{nd}$ & $\begin{array}{l}53.0^{\mathrm{b}} \\
(4.2)\end{array}$ & $\begin{array}{l}1.3^{\mathrm{b}} \\
(0.1)\end{array}$ & $\begin{array}{l}39.6^{\mathrm{b}} \\
(0.2)\end{array}$ & $\begin{array}{l}0.34^{\text {cd }} \\
(0.01)\end{array}$ & $\begin{array}{l}0.26^{\mathrm{b}} \\
(0.01)\end{array}$ & - \\
\hline $3 \mathrm{rd}$ & $\begin{array}{l}39.7^{\mathrm{bc}} \\
(5.4)\end{array}$ & $\begin{array}{l}1.8^{\mathrm{b}} \\
(0.4)\end{array}$ & $\begin{array}{l}23.1^{\mathrm{c}} \\
(1.6)\end{array}$ & $\begin{array}{l}0.42^{\mathrm{c}} \\
(0.02)\end{array}$ & $\begin{array}{l}0.31^{\mathrm{a}} \\
(0.01)\end{array}$ & - \\
\hline 4th & $\begin{array}{l}14.3^{\mathrm{cd}} \\
(1.5)\end{array}$ & $\begin{array}{l}1.4^{\mathrm{b}} \\
(0.1)\end{array}$ & $\begin{array}{l}10.0^{\mathrm{d}} \\
(0.8)\end{array}$ & $\begin{array}{l}0.62^{\mathrm{b}} \\
(0.02)\end{array}$ & $\begin{array}{l}0.33^{\mathrm{a}} \\
(0.00)\end{array}$ & - \\
\hline 5 th & $\begin{array}{l}8.0^{\mathrm{d}} \\
(0.8)\end{array}$ & $\begin{array}{l}3.4^{\mathrm{a}} \\
(0.5)\end{array}$ & $\begin{array}{r}2.4^{\mathrm{e}} \\
(0.3)\end{array}$ & $\begin{array}{l}1.26^{\mathrm{a}} \\
(0.06)\end{array}$ & $\begin{array}{l}0.33^{\mathrm{a}} \\
(0.01)\end{array}$ & - \\
\hline
\end{tabular}

TRL is total root length; SRL specific root length; RTD root tissue density. Data are expressed as means \pm standard error in parentheses. Different superscript letters within each column represent significant differences $(p<0.05)$ among root orders. Dashes indicate unmeasured parameters

fifth order (Table 1). SRL was negatively correlated with root order and sharply decreased from $48.2 \mathrm{~m} \mathrm{~g}^{-1}$ in the first order to $2.4 \mathrm{~m} \mathrm{~g}^{-1}$ in the fifth order (Table 1). The first and second order roots had similar mean diameter, and beyond the second order mean diameter increased significantly with root order. RTD of the first two root orders were significantly lower than those of third to fifth root orders with the minimum and maximum of $0.26 \mathrm{~g} \mathrm{~cm}^{-3}$ in the second order to $0.33 \mathrm{~g} \mathrm{~cm}^{-3}$ in the fifth order, respectively. Root tips colonized by EM fungi accounted for $71 \%$ of the total root tips (Table 1 ).

Responses of fine root functional parameters to exogenous $\mathrm{N}$ addition

Fine root growth, morphological traits, and EM tip colonization responded differentially to exogenous $\mathrm{N}$ addition (Fig. 1). Root biomass, TRL in all root orders, and EM tip colonization were significantly increased by $\mathrm{N}$ addition (Fig. 1). However, SRL, RTD, and root diameter remain unchanged in any root orders (data not shown). Specifically, the average biomass of the lower-order roots (the first three orders) and higherorder roots (the 4th and 5th orders) in $\mathrm{N}$ addition plots were 1.5-fold and 1.2-fold higher than those in control plots (Fig. 1a and d). The average TRL of the lowerorder roots and higher-order roots in $\mathrm{N}$ addition plots were 1.3-fold and 1.6-fold higher than those in control plots (Fig. 1b and e). EM tip colonization was significantly increased on average by $12 \%$ in response to exogenous $\mathrm{N}$ addition (Fig. 1c and $\mathrm{f}$ ).

In general, the responses of root biomass, TRL, and EM tip colonization to $\mathrm{N}$ addition were dependent both on $\mathrm{N}$ dose and on $\mathrm{N}$ species (Table 2). Irrespective of $\mathrm{N}$ doses (40 vs. $120 \mathrm{~kg} \mathrm{~N} \mathrm{ha}^{-1} \mathrm{yr}^{-1}$ ) added, ammoniumbased $\mathrm{N}$ input exerted larger effects on the biomass, TRL, and EM tip colonization than nitrate-based $\mathrm{N}$ input (Table 2; Fig. 1a-c). A significant difference between ammonium- and nitrate- based $\mathrm{N}$ input was observed in the biomass and TRL of the lower-order roots (Fig. 1a and b). Regardless of $\mathrm{N}$ species $\left(\mathrm{NH}_{4} \mathrm{Cl}\right.$ vs. $\mathrm{NaNO}_{3}$ ) applied, high doses of $\mathrm{N}$ addition exerted stronger effects on the root biomass, TRL, and EM tip colonization than low doses of $\mathrm{N}$ addition (Table 2; Fig. 1d-f). A significant difference between low- and high-doses of $\mathrm{N}$ addition was observed in the biomass and TRL of the lower-order roots as well as in the EM tip colonization (Fig. 1d-f).

\section{Responses of soil and foliar chemistry to $\mathrm{N}$ addition}

After 1.5 years of $\mathrm{N}$ addition, soil $\mathrm{NH}_{4}{ }^{+}$was significantly increased by $67.2 \%$ in response to high dose of $\mathrm{NH}_{4} \mathrm{Cl}$ addition, and slightly increased by remaining three $\mathrm{N}$ addition treatments (Fig. 2a). Soil $\mathrm{NO}_{3}{ }^{-}$was significantly increased by high doses of $\mathrm{N}$ addition (Fig. 2b) and was on average 3.5-fold higher than that of control $\left(2.38 \mathrm{mg} \mathrm{kg}^{-1}\right)$. Soil $\mathrm{pH}$ was significantly decreased on average by 0.4 units in response to $\mathrm{N}$ addition, except the high dose of $\mathrm{NaNO}_{3}$ input (Fig. 2c).

Foliar $\mathrm{N}$ content was significantly increased by low doses of $\mathrm{N}$ addition (Fig. 2d), increasing on average by $1.5 \mathrm{mg} \mathrm{g}^{-1}$, but was only slightly increased under high doses of $\mathrm{N}$ addition. Conversely, a significant decrease in foliar $\mathrm{P}$ content was observed due to high dose of $\mathrm{NH}_{4} \mathrm{Cl}$ input (Fig. 2e), which was decreased by 

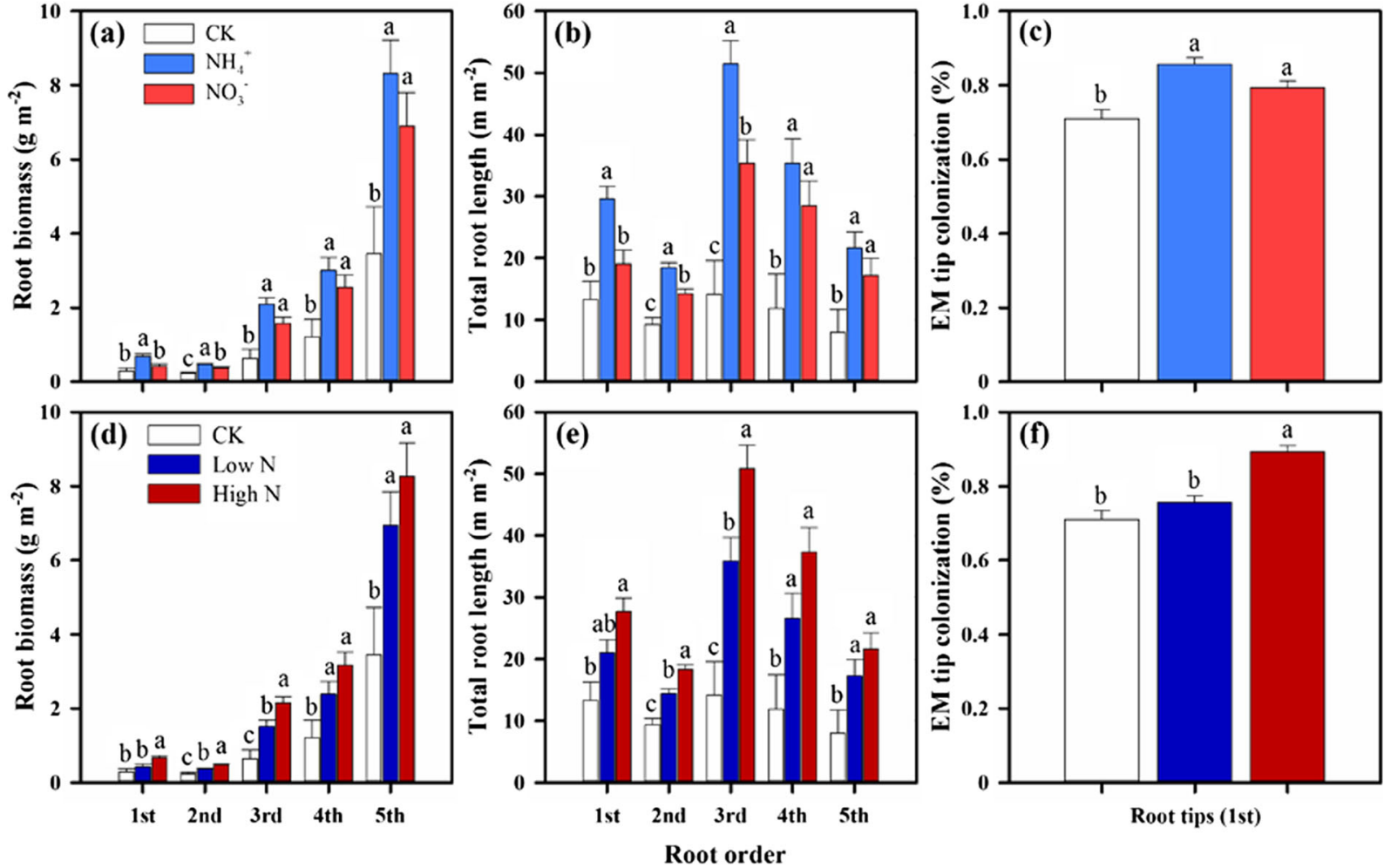

Fig. 1 Effects of $\mathrm{N}$ species (a, $\mathbf{b}$, and $\mathbf{c}$ respectively) and doses (d, $\mathbf{e}$, and $\mathbf{f}$ respectively) on root biomass, TRL across five root orders standard error $(n=3, p<0.05)$. Different letters represent statistical and on EM tip colonization. Data are expressed as means \pm significances among treatments

Table 2 Effects of $\mathrm{N}$ dose, $\mathrm{N}$ species, and their interactions on TRL, root biomass, SRL, root diameter, and RTD for five root orders and on EM tip colonization

\begin{tabular}{|c|c|c|c|c|c|c|c|}
\hline Root order & Sources of variation & $\begin{array}{l}\text { TRL } \\
\mathrm{F}(p)\end{array}$ & $\begin{array}{l}\text { Biomass } \\
\mathrm{F}(p)\end{array}$ & $\begin{array}{l}\text { SRL } \\
\mathrm{F}(p)\end{array}$ & $\begin{array}{l}\text { Diameter } \\
\mathrm{F}(p)\end{array}$ & $\begin{array}{l}\text { RTD } \\
\mathrm{F}(p)\end{array}$ & $\begin{array}{l}\text { EM tip colonization } \\
\mathrm{F}(p)\end{array}$ \\
\hline \multirow[t]{3}{*}{$1 \mathrm{st}$} & $\mathrm{N}$ dose & $9.60(0.001)$ & $10.08(0.001)$ & $0.60(0.56)$ & $0.05(0.95)$ & $1.46(0.26)$ & $20.43(<0.001)$ \\
\hline & $\mathrm{N}$ species & $12.55(<0.001)$ & $11.43(0.001)$ & $0.11(0.893)$ & $0.09(0.91)$ & $0.76(0.48)$ & $12.18(<0.001)$ \\
\hline & $\mathrm{N}$ dose $\times \mathrm{N}$ species & $5.48(0.005)$ & $4.00(0.02)$ & $0.54(0.71)$ & $0.05(0.99)$ & $1.72(0.19)$ & $6.24(0.002)$ \\
\hline \multirow[t]{3}{*}{2 nd } & $\mathrm{N}$ dose & $31.73(<0.001)$ & $35.53(<0.001)$ & $0.56(0.58)$ & $0.20(0.82)$ & $2.20(0.14)$ & - \\
\hline & $\mathrm{N}$ species & $32.86(<0.001)$ & $32.73(<0.001)$ & $1.77(0.20)$ & $0.06(0.94)$ & $3.43(0.06)$ & - \\
\hline & $\mathrm{N}$ dose $\times \mathrm{N}$ species & $13.90(<0.001)$ & $13.41(<0.001)$ & $0.46(0.77)$ & $0.20(0.94)$ & $1.31(0.30)$ & 一 \\
\hline \multirow[t]{3}{*}{$3 \mathrm{rd}$} & $\mathrm{N}$ dose & $25.52(<0.001)$ & $19.81(<0.001)$ & $0.23(0.80)$ & $0.09(0.92)$ & $0.75(0.49)$ & - \\
\hline & $\mathrm{N}$ species & $26.15(<0.001)$ & $18.81(<0.001)$ & $0.30(0.75)$ & $0.05(0.96)$ & $0.97(0.40)$ & - \\
\hline & $\mathrm{N}$ dose $\times \mathrm{N}$ species & $7.78(0.001)$ & $5.65(0.004)$ & $0.27(0.90)$ & $0.20(0.93)$ & $0.38(0.82)$ & 一 \\
\hline \multirow[t]{3}{*}{4 th } & $\mathrm{N}$ dose & $57.87(<0.001)$ & $14.31(<0.001)$ & $1.11(0.35)$ & $0.05(0.95)$ & $0.89(0.36)$ & - \\
\hline & $\mathrm{N}$ species & $56.87(<0.001)$ & $13.57(<0.001)$ & $1.33(0.29)$ & $0.11(0.90)$ & $1.63(0.22)$ & - \\
\hline & $\mathrm{N}$ dose $\times \mathrm{N}$ species & $14.67(<0.001)$ & $3.83(0.02)$ & $0.49(0.74)$ & $0.75(0.57)$ & $1.09(0.43)$ & - \\
\hline \multirow[t]{3}{*}{5 th } & $\mathrm{N}$ dose & $13.25(<0.001)$ & $9.12(0.002)$ & $0.06(0.94)$ & $0.30(0.74)$ & $1.38(0.28)$ & - \\
\hline & $\mathrm{N}$ species & $13.37(<0.001)$ & $9.26(0.002)$ & $0.20(0.82)$ & $0.70(0.51)$ & $2.56(0.11)$ & - \\
\hline & $\mathrm{N}$ dose $\times \mathrm{N}$ species & $3.35(0.03)$ & $2.36(0.09)$ & $0.07(0.99)$ & $0.29(0.88)$ & $0.68(0.61)$ & - \\
\hline
\end{tabular}




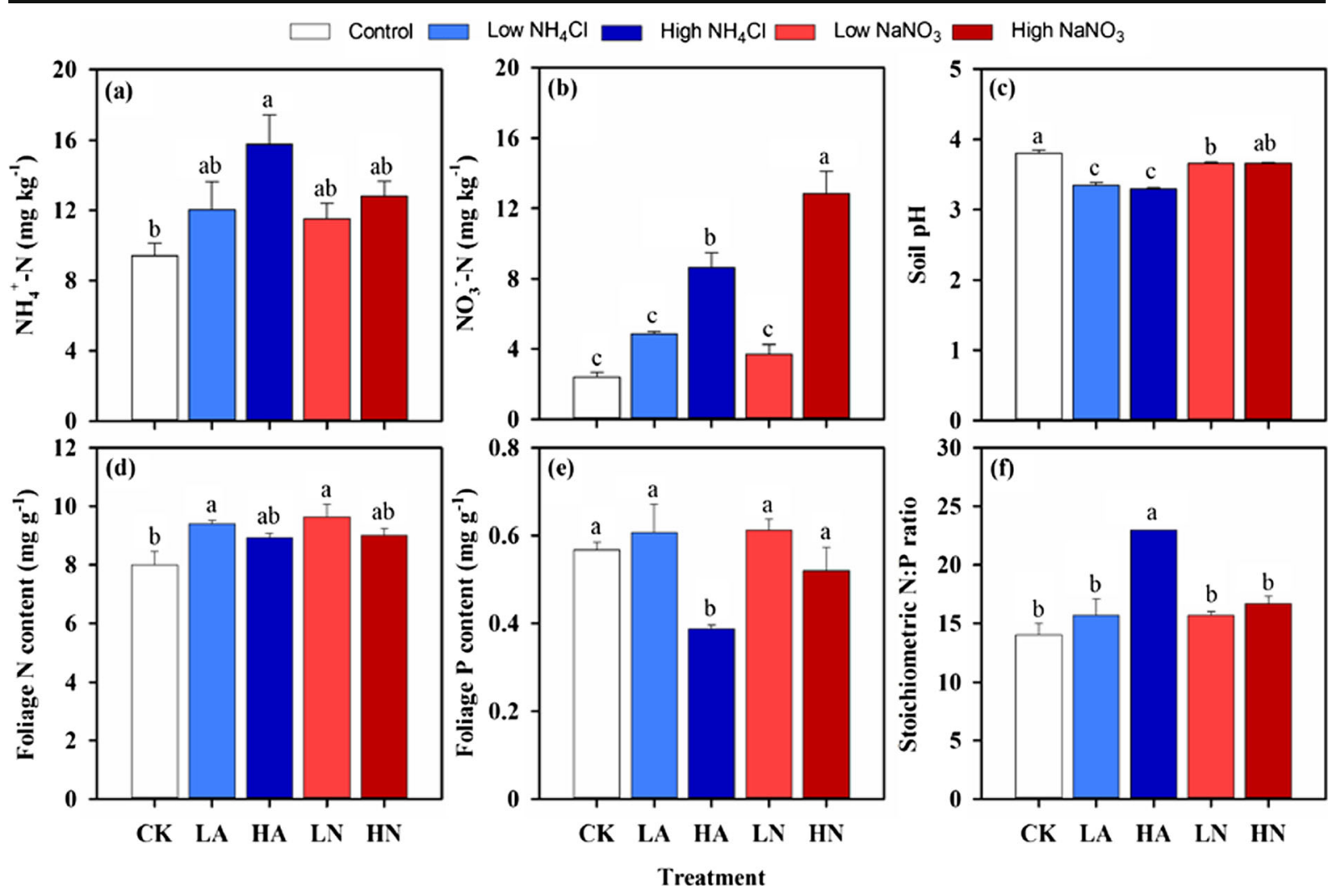

Fig. 2 Effects of $\mathrm{N}$ fertilization on soil $\left(\mathrm{NH}_{4}{ }^{+}-\mathrm{N}, \mathrm{NO}_{3}{ }^{-}-\mathrm{N}\right.$, and $\left.\mathrm{pH}\right)$ and foliar $(\mathrm{N}, \mathrm{P}$ content and stoichiometric $\mathrm{N}: \mathrm{P}$ ratio) chemistry. Data are expressed as means \pm standard error $(n=3, p<0.05)$. Different letters represent statistical significances among different treatments

$0.18 \mathrm{mg} \mathrm{g}^{-1}$. However, no significant difference was observed between the control and the remaining $\mathrm{N}$ treatments. The foliar stoichiometric N:P ratio was significantly increased by high dose of $\mathrm{NH}_{4} \mathrm{Cl}$ addition (Fig. 2f). However, the other three $\mathrm{N}$ treatments contributed slightly to the change in foliar N:P ratios. The foliar stoichiometric $\mathrm{N}: \mathrm{P}$ ratios among all treatments ranged from 14 (control) to 23 (high dose of $\mathrm{NH}_{4} \mathrm{Cl}$ ).

Relationships between root parameters and foliar chemistry

Fine root growth and EM tip colonization presented inconsistent relations with foliar N, P and stoichiometric $\mathrm{N}: \mathrm{P}$ ratio. Specifically, no significant correlations were observed between the foliar $\mathrm{N}$ content and any of the parameters (TRL, root biomass, and EM tip colonization) (Fig. 3a, d and g). However, these parameters were negatively related to the foliar P content (Fig. 3b, e and h), and positively related to the stoichiometric $\mathrm{N}: \mathrm{P}$ ratio (Fig. 3c, f and i).

\section{Discussion}

Plastic responses of fine root functional parameters to $\mathrm{N}$ addition

Different fine root parameters showed differential responses to exogenous $\mathrm{N}$ addition (Fig. 1). The significant responses observed in TRL, root biomass, and EM tip colonization (Fig. 1) may indicate their intimate relations with nutrient acquisition (Lõhmus et al. 2006) and confirm previous studies on the extensive (increased root growth) or intensive foraging strategies (enhanced mycorrhizal symbiosis) (Helmisaari et al. 2009; Ostonen et al. 2011). The varying plastic response of fine root parameters may also imply their contrasting phylogenetic conservatism (Comas et al. 2002; Comas and Eissenstat 2004; Adams et al. 2013). Kong et al. (2014) has shown that root diameter and RTD have greater Blomberg's $K$ values (an index assessing the phylogenetical conservativeness of different biological traits) (Blomberg et al. 2003) among 14 root functional traits, implying that they are phylogenetically 


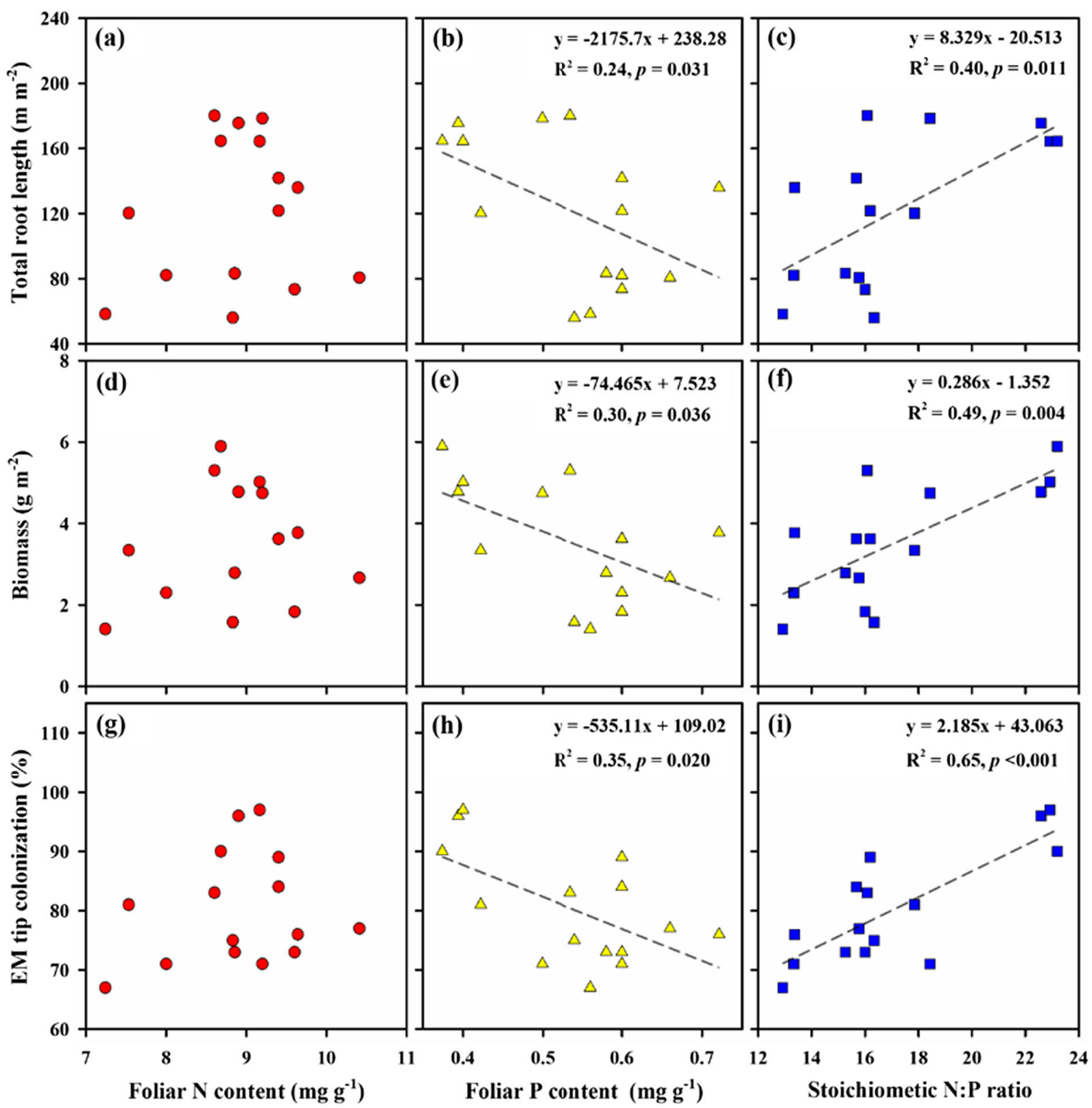

Fig. 3 Relationships between foliar chemistry (N, P contents and stoichiometric N:P ratio) and fine root parameters (TRL, root biomass, and EM tip colonization) significantly responsive to $\mathrm{N}$

conservative within species and poorly plastic in response to changing soil environment. SRL is considered to be indicative of interspecific differences in environmental change response (Ostonen et al. 2007), but it may be less responsive to $\mathrm{N}$ addition within species (George et al. 1997; Mei et al. 2010). Our results showed that SRL did not change with $\mathrm{N}$ addition (data not shown). This concurs with the recent study of addition among all the treatments $(p<0.05)$. Data for TRL and biomass were means of the absorptive roots (i.e., the first three root orders)

Tobner et al. (2013) who reported that SRL did not vary with changing soil conditions. Despite of strongly plastic responses in TRL and biomass, we found that they co-varied significantly with respect to root order (Fig. S1), which may be responsible for the lack of response in SRL. Furthermore, SRL is inherently codetermined by root diameter and RTD based on the equation deduced in Ostonen et al. (2007). Thus, the 
conservatism in root diameter and RTD may provide an alternative explanation for the absent response in SRL.

Higher-order roots structurally supportive of lowerorder roots were also responsive to exogenous $\mathrm{N}$ addition (Fig. 1). Lower-order non-woody roots rather than lignified higher-order roots have been shown to be the short-lived modular structures that are probably mainly responsible for resource uptake in plants (Xia et al. 2010). Thus, the simultaneous increases in higherorder roots and lower-order roots (Fig. 1) inevitably cause an increase of the cost (carbohydrate) of investment into roots according to the theory of cost-benefit analysis (Eissenstat and Yanai 1997). However, we found abundant understory species at the site (Table S1) where niche overlapping may occur. This may be largely responsible for the increase in higherorder roots. Interspecies competition generally reduces the total amount of roots that plants deploy in a given size of soil volume (Casper and Jackson 1997; Goldberg et al. 1999). Moreover, avoidance strategy has been suggested to be the most common behavioral type of plants in response to neighbor cues (Dudley and File 2007; Cahill and McNickle 2011). Therefore, as a patch was occupied or depleted, higher-order roots may penetrate more deeply or expand more extensively in the soil to develop lower-order roots for nutrient foraging and meanwhile provide a persistently physical support (Pregitzer et al. 2002; Callaway et al. 2003).

Contrasting effects of varying doses and species of $\mathrm{N}$ addition

Fine root growth and EM tip colonization in our study responded differently to varying species of $\mathrm{N}$ addition (Table 2; Fig. 1). Plants have preferences for inorganic $\mathrm{N}$ species both in the field (Nordin et al. 2001; Kahmen et al. 2008) and pot experiments (Falkengren-Grerup 1995; Nicodemus et al. 2008). Our finding showed that the effect of ammonium-based $\mathrm{N}$ on lower-order root growth is greater than that of nitrate-based $\mathrm{N}$ input $(p<0.001$, Table 2; Fig. 1a-c). This may be related to the fact that higher energy expenditure would be required to assimilate $\mathrm{NO}_{3}{ }^{-}$than $\mathrm{NH}_{4}{ }^{+}$(Hageman 1980). Another explanation may be the particular N-retention mechanisms in acidic forest soils in southern China. Zhang et al. (2013) reported that $\mathrm{NO}_{3}{ }^{-}$could be efficiently immobilized into organic $\mathrm{N}$ pool in the acidic soil. Consequently, fine root would respond strongly to ammonium-based $\mathrm{N}$ input, as nitrate-based $\mathrm{N}$ supply failed to meet the demand of the plants for N. Additionally, $\mathrm{NH}_{4}{ }^{+}$is less mobile in the soil than $\mathrm{NO}_{3}{ }^{-}$which is labile to leach with high precipitation in this region (Clarke and Barley 1968). Hence, the difference in capacity of ion mobility may contribute to the differential responses of fine root to ammonium- and nitratebased $\mathrm{N}$ added.

Supporting our second hypothesis, responses of fine root growth and EM tip colonization to $\mathrm{N}$ addition are dependent upon the dose of $\mathrm{N}$ supplied (Table 2; Fig. 1). We found that lower-order root parameters were more responsive to high doses of $\mathrm{N}$ input ( $120 \mathrm{~kg} \mathrm{~N} \mathrm{ha}^{-1} \mathrm{yr}^{-1}$ ) than to low doses of $\mathrm{N}$ input $\left(40 \mathrm{~kg} \mathrm{~N}^{-1} \mathrm{yr}^{-1}\right)$ $(p<0.001$, Table 2; Fig. 1d-f). Our result is similar to the observations of Wang et al. (2013) that absorptive root traits responded more strongly to higher dose of $\mathrm{N}$ addition (90 kg N ha $\mathrm{yr}^{-1}$ input of urea). This implies that lower-order root parameters in $\mathrm{N}$-limited forests would change more strongly under high doses of $\mathrm{N}$ addition or as $\mathrm{N}$ addition exceeds a threshold. In our study, we did not exclude the role of $\mathrm{N}$ uptake by understorey neighbor plants and $\mathrm{N}$ immobilization by soil microorganisms that may hinder $\mathrm{N}$ acquisition by the slash pine trees, weaken the sensing of plant to exogenous $\mathrm{N}$, and subsequently only relatively less carbon (C) be allocated into roots (Hermans et al. 2006). In addition, the efficient immobilization of $\mathrm{NO}_{3}{ }^{-}$may similarly explain the relatively weak response to low dose of nitrate-based $\mathrm{N}$ supply.

Driving factors for the increased TRL, root biomass, and EM tip colonization

Root biomass and TRL were significantly increased in response to $\mathrm{N}$ addition (Fig. 1a, b, d and e), and this finding seems to be related to low $\mathrm{P}$ at our study site. Our result is not consistent with the findings of Wang et al. (2013) who reported that $\mathrm{N}$ addition significantly reduced the TRL and root biomass in an N-limited forest. Literature has reported that deficiency of nutrients (e.g., $\mathrm{N}$ and $\mathrm{P}$ ) generally results in an accumulation of carbohydrates in roots (Hermans et al. 2006). Thus, the decrease of $\mathrm{C}$ allocation to belowground observed by Wang et al. (2013) may be due to the ameliorated $\mathrm{N}$ limitation to plant growth after three years of $\mathrm{N}$ addition and due to sufficient $\mathrm{P}$ supply from soil. Stoichiometric ratios have proved useful to investigate shift in nutrient limitation, especially $\mathrm{N}$ and $\mathrm{P}$ (Koerselman and Meuleman 1996; Güsewell and Koerselman 2002; 
Wang and Moore 2014). The plantation in our study is originally limited by $\mathrm{N}$ and $\mathrm{P}$ at vegetation level (Fig. S2) based on the foliar N:P ratio threshold values suggested by Güsewell (2004). However, the foliar N:P ratio was significantly increased by high dose of $\mathrm{NH}_{4} \mathrm{Cl}$ addition (approaching to 25) and slightly increased by the remaining three $\mathrm{N}$ treatments (Fig. 2f). Moreover, we noticed that at soil level, soil inorganic $\mathrm{N}$ was also significantly or slightly increased by exogenous $\mathrm{N}$ input (Fig. 2a and b), which may in parallel indicate alleviation of $\mathrm{N}$ limitation and persistent or aggravated $\mathrm{P}$ limitation in P. elliottii plantation.

Mycorrhizal symbiosis provides an effective pathway by which plants can acclimate themselves to Pdeficient environments (Plassard and Dell 2010). As N limitation was alleviated in our study, the increase in EM tip colonization might be primarily triggered by $\mathrm{P}$ limitation (Fig. 1c and f). This agrees with the metaanalysis results from Treseder (2004) in which mycorrhizal colonization rate was negatively related to $\mathrm{P}$ availability. Increased mycorrhizal colonization may facilitate $P$. elliottii more than non-mycorrhizal plants and soil free microorganisms in competition for nutrients, especially immobile P (Bünemann et al. 2010; Kuzyakov and Xu 2013). On the other hand, the intensified mycorrhizal dependence may also imply the possibility that $P$. elliottii per se has poor ability to acquire sufficient nutrients in presence of nutrient competition.

Although P limitation may drive fine root growth and EM tip colonization, the foliar P content was not increased (Fig. 2e) and the foliar N:P ratio remained relatively constant, except the value under high dose of $\mathrm{NH}_{4} \mathrm{Cl}$ input (Fig. 2d). This indicates that plants may maintain low nutrient contents in photosynthetically active tissues and constant nutrient ratios to adapt to low nutrient availability and to keep stoichiometric homeostasis (Wang and Moore 2014). The decreased $\mathrm{P}$ content and increased $\mathrm{N}: \mathrm{P}$ ratio in high dose of $\mathrm{NH}_{4} \mathrm{Cl}$ addition plots may be associated with decreased soil $\mathrm{pH}$ (Fig. 2c), which may accelerate the fixation of labile inorganic $\mathrm{P}$ and thus aggravate soil $\mathrm{P}$ limitation (Matson et al. 1999; Gradowski and Thomas 2006). We observed no significant correlations between the foliar $\mathrm{N}$ content and any of the parameters (TRL, root biomass, and EM tip colonization), which were significantly responsive to $\mathrm{N}$ addition (Fig. 3a, d and g). However, these parameters were negatively related to the foliar P content (Fig. 3b, e and $h$ ), and positively related to the stoichiometric N:P ratio (Fig. 3c, f and i). Hence, the plastic responses in root biomass, TRL, and EM tip colonization in our study may be to a great extent driven by the persistent or aggravated $\mathrm{P}$ limitation as $\mathrm{N}$ limitation to plant growth was alleviated by exogenous $\mathrm{N}$ input.

\section{Conclusions}

The present study shows that fine root growth and EM tip colonization respond more strongly to $\mathrm{N}$ addition than fine root morphological traits in a P. elliottii (slash pine) plantation in subtropical China, indicating their stronger plasticity and foraging capacity for nutrients. Lower-order root responded differently to doses and species of $\mathrm{N}$ added, which is likely ascribed to plant $\mathrm{N}$ uptake preference. Since N deposition is still escalating, increased absorptive root length, root biomass, and/or dependence on ectomycorrhiza for nutrient foraging are appreciably helpful for growth of EM species. Despite alleviation of $\mathrm{N}$ limitation, the persistent or aggravated $\mathrm{P}$ limitation might strongly affect the responses of fine root parameters to $\mathrm{N}$ addition. In this study, we did not directly test the P effects on fine root growth, morphological traits, and EM tip colonization of $P$. elliottii, but based on the foliar P content, stoichiometric N:P ratio and soil chemical properties. Further studies are therefore needed in future to combine $\mathrm{N}$ with $\mathrm{P}$ additions to verify our observations and to quantify the role that dominating EM fungi plays in adjusting nutrientforaging strategy of the slash pine plantation.

Acknowledgments This research is financially supported by the grants from the National Natural Science Foundation of China (No. 31130009) and the National Key Project of Scientific and Technical Supporting Program (No. 2013BAC03B03). Special thanks are due to the Qianyanzhou Experimental Station of Red Soil and Hilly Land, Chinese Academy of Sciences, Jiangxi province, China, for permission to work in their permanent slash pine plantation experiment plots. Thanks to all the staff and students of the Qianyanzhou Experimental Station for their assistance in the field work. The authors acknowledge the contributions of the anonymous reviewers.

\section{References}

Aber JD, Nadelhoffer KJ, Steudler P, Melillo JM (1989) Nitrogen Saturation in Northern Forest Ecosystems. Bioscience 39: 378-386

Adams TS, McCormack ML, Eissenstat DM (2013) Foraging strategies in trees of different root morphology: the role of root lifespan. Tree Physiol 33:940-948 
Blomberg SP, Garland T, Ives AR (2003) Testing for phylogenetic signal in comparative data: behavioral traits are more labile. Evolution 57:717-745

Bolan NS (1991) A critical-review on the role of mycorrhizal fungi in the uptake of phosphorus by plants. Plant Soil 134:189-207

Braun S, Thomas VFD, Quiring R, Fluckiger W (2010) Does nitrogen deposition increase forest production? The role of phosphorus. Environ Pollut 158:2043-2052

Bünemann EK, Oberson A, Frossard E (2010) Phosphorus in action: biological processes in soil phosphorus cycling. Springer, Berlin

Cahill JF Jr, McNickle GG (2011) The behavioral ecology of nutrient foraging by plants. Annu Rev Ecol Evol Syst 42: 289-311

Cairney JWG (2011) Ectomycorrhizal fungi: the symbiotic route to the root for phosphorus in forest soils. Plant Soil 344:51-71

Callaway RM, Pennings SC, Richards CL (2003) Phenotypic plasticity and interactions among plants. Ecology 84:11151128

Casper BB, Jackson RB (1997) Plant competition underground. Annu Rev Ecol Syst 28:545-570

Clarke A, Barley K (1968) The uptake of nitrogen from soils in relation to solute diffusion. Soil Res 6:75-92

Comas LH, Eissenstat DM (2004) Linking fine root traits to maximum potential growth rate among 11 mature temperate tree species. Funct Ecol 18:388-397

Comas LH, Bouma TJ, Eissenstat DM (2002) Linking root traits to potential growth rate in six temperate tree species. Oecologia 132:34-43

Danielsen L, Lohaus G, Sirrenberg A, Karlovsky P, Bastien C, Pilate G, Polle A (2013) Ectomycorrhizal Colonization and Diversity in Relation to Tree Biomass and Nutrition in a Plantation of Transgenic Poplars with Modified Lignin Biosynthesis. Plos One 8

Dudley SA, File AL (2007) Kin recognition in an annual plant. Biol Lett 3:435-438

Eissenstat DM, Yanai RD (1997) The ecology of root lifespan. Adv Ecol Res 27:1-60

Falkengren-Grerup U (1995) Interspecies Differences in the Preference of Ammonium and Nitrate in Vascular Plants. Oecologia 102:305-311

Galloway JN, Townsend AR, Erisman JW, Bekunda M, Cai ZC, Freney JR, Martinelli LA, Seitzinger SP, Sutton MA (2008) Transformation of the nitrogen cycle: recent trends, questions and potential solutions. Science 320:889-892

George E, Seith B, Schaeffer C, Marschner H (1997) Responses of Picea, Pinus and Pseudotsuga roots to heterogeneous nutrient distribution in soil. Tree Physiol 17:39-45

Goldberg DE, Rajaniemi T, Gurevitch J, Stewart-Oaten A (1999) Empirical approaches to quantifying interaction intensity: competition and facilitation along productivity gradients. Ecology 80:1118-1131

Gradowski T, Thomas SC (2006) Phosphorus limitation of sugar maple growth in central Ontario. For Ecol Manag 226:104-109

Guo DL, Mitchell RJ, Hendricks JJ (2004) Fine root branch orders respond differentially to carbon source-sink manipulations in a longleaf pine forest. Oecologia 140:450-457

Guo DL, Xia MX, Wei X, Chang WJ, Liu Y, Wang ZQ (2008) Anatomical traits associated with absorption and mycorrhizal colonization are linked to root branch order in twenty-three Chinese temperate tree species. New Phytol 180:673-683
Guo YY, Wang JJ, Kong DL, Wang W, Guo DL, Wang YB, Xie QL, Liu YS, Zeng H (2013) Fine root branch orders contribute differentially to uptake, allocation, and return of potentially toxic metals. Environ Sci Technol 47:11465-11472

Güsewell S (2004) N:P ratios in terrestrial plants: variation and functional significance. New Phytol 164:243-266

Güsewell S, Koerselman M (2002) Variation in nitrogen and phosphorus concentrations of wetland plants. Perspect Plant Ecol 5:37-61

Hageman R (1980) Effect of form of nitrogen on plant growth. In: Meisinger JJ, Randall GW, Vitosh ML, Stelly M, Kroll DM, Cousin MK (eds) Nitrification Inhibitors-Potentials and Limitations, Spec publ ASA 38. Am Soc of Agron and Soil Sci Soc of Am, Madison, pp 47-62

Helmisaari HS, Ostonen I, Lõhmus K, Derome J, Lindroos AJ, Merila P, Nojd P (2009) Ectomycorrhizal root tips in relation to site and stand characteristics in Norway spruce and Scots pine stands in boreal forests. Tree Physiol 29:445-456

Hermans C, Hammond JP, White PJ, Verbruggen N (2006) How do plants respond to nutrient shortage by biomass allocation? Trends Plant Sci 11:610-617

Hodge A (2006) Plastic plants and patchy soils. J Exp Bot 57:401411

Kahmen A, Wanek W, Buchmann N (2008) Foliar $\delta^{15} \mathrm{~N}$ values characterize soil $\mathrm{N}$ cycling and reflect nitrate or ammonium preference of plants along a temperate grassland gradient. Oecologia 158:371

Koerselman W, Meuleman AFM (1996) The vegetation N:P ratio: a new tool to detect the nature of nutrient limitation. J Appl Ecol 33:1441-1450

Kong DL, Ma CE, Zhang Q, Li L, Chen XY, Zeng H, Guo DL (2014) Leading dimensions in absorptive root trait variation across 96 subtropical forest species. New Phytol 203:863872

Kuzyakov Y, Xu XL (2013) Competition between roots and microorganisms for nitrogen: mechanisms and ecological relevance. New Phyto 198:656-669

Leuschner C, Gebel S, Rose L (2013) Root trait responses of six temperate grassland species to intensive mowing and NPK fertilisation: a field study in a temperate grassland. Plant Soil 373:687-698

Lima JE, Kojima S, Takahashi H, von Wiren N (2010) Ammonium triggers lateral root branching in Arabidopsis in an AMMONIUM TRANSPORTER1;3-dependent manner. Plant Cell 22:3621-3633

Linkohr BI, Williamson LC, Fitter AH, Leyser HMO (2002) Nitrate and phosphate availability and distribution have different effects on root system architecture of Arabidopsis. Plant J 29:751-760

Lõhmus K, Truu M, Truu J, Ostonen I, Kaar E, Vares A, Uri V, Alama S, Kanal A (2006) Functional diversity of culturable bacterial communities in the rhizosphere in relation to fineroot and soil parameters in alder stands on forest, abandoned agricultural, and oil-shale mining areas. Plant Soil 283:1-10

Matson PA, McDowell WH, Townsend AR, Vitousek PM (1999) The globalization of $\mathrm{N}$ deposition: ecosystem consequences in tropical environments. Biogeochemistry 46:67-83

Mei L, Gu JC, Zhang ZW, Wang ZQ (2010) Responses of fine root mass, length, production and turnover to soil nitrogen fertilization in Larix gmelinii and Fraxinus mandshurica forests in Northeastern China. J For Res 15:194-201 
Meier IC, Leuschner C (2008) Genotypic variation and phenotypic plasticity in the drought response of fine roots of European beech. Tree Physiol 28:297-309

Mou P, Jones RH, Tan ZQ, Bao Z, Chen HM (2013) Morphological and physiological plasticity of plant roots when nutrients are both spatially and temporally heterogeneous. Plant Soil 364:373-384

Nicodemus MA, Salifu KF, Jacobs DF (2008) Nitrate reductase activity and nitrogen compounds in xylem exudate of Juglans nigra seedlings: relation to nitrogen source and supply. TreesStruct Funct 22:685-695

Noguchi K, Nagakura J, Kaneko S (2013) Biomass and morphology of fine roots of sugi (Cryptomeria japonica) after 3 years of nitrogen fertilization. Front Plant Sci $4: 347$

Nordin A, Hogberg P, Nasholm T (2001) Soil nitrogen form and plant nitrogen uptake along a boreal forest productivity gradient. Oecologia 129:125-132

Ostonen I, Puttsepp U, Biel C, Alberton O, Bakker MR, Lõhmus K, Majdi H, Metcalfe D, Olsthoorn AFM, Pronk A, Vanguelova E, Weih M, Brunner I (2007) Specific root length as an indicator of environmental change. Plant Biosyst 141: 426-442

Ostonen I, Helmisaari HS, Borken W, Tedersoo L, Kukumagi M, Bahram M, Lindroos AJ, Nojd P, Uri V, Merila P, Asi E, Lõhmus K (2011) Fine root foraging strategies in Norway spruce forests across a European climate gradient. Glob Chang Biol 17:3620-3632

Plassard C, Dell B (2010) Phosphorus nutrition of mycorrhizal trees. Tree Physiol 30:1129-1139

Pregitzer KS, DeForest JL, Burton AJ, Allen MF, Ruess RW, Hendrick RL (2002) Fine root architecture of nine North American trees. Ecol Monogr 72:293-309

Rewald B, Ephrath JE, Rachmilevitch S (2011) A root is a root is a root? Water uptake rates of Citrus root orders. Plant Cell Environ 34:33-42
Teste FP, Veneklaas EJ, Dixon KW, Lambers H (2014) Complementary plant nutrient-acquisition strategies promote growth of neighbour species. Funct Ecol 28:819-828

Tobner CM, Paquette A, Messier C (2013) Interspecific coordination and intraspecific plasticity of fine root traits in North American temperate tree species. Front Plant Sci 4:242

Treseder KK (2004) A meta-analysis of mycorrhizal responses to nitrogen, phosphorus, and atmospheric $\mathrm{CO}_{2}$ in field studies. New Phytol 164:347-355

Wang M, Moore TR (2014) Carbon, nitrogen, phosphorus, and potassium stoichiometry in an ombrotrophic peatland reflects plant functional type. Ecosystems 17:673-684

Wang YD, Wang ZL, Wang HM, Guo CC, Bao WK (2012) Rainfall pulse primarily drives litterfall respiration and its contribution to soil respiration in a young exotic pine plantation in subtropical China. Can J For Res 42:657-666

Wang GL, Fahey TJ, Xue S, Liu F (2013) Root morphology and architecture respond to $\mathrm{N}$ addition in Pinus tabuliformis, west China. Oecologia 171:583-590

Wen XF, Wang HM, Wang JL, Yu GR, Sun XM (2010) Ecosystem carbon exchanges of a subtropical evergreen coniferous plantation subjected to seasonal drought, 2003-2007. Biogeosciences 7:357-369

Xia MX, Guo DL, Pregitzer KS (2010) Ephemeral root modules in Fraxinus mandshurica. New Phytol 188:1065-1074

Zhan XY, Yu GR, He NP, Fang HJ, Jia BR, Zhou M, Wang CK, Zhang JH, Zhao GD, Wang SL, Liu YF, Yan JH (2014) Nitrogen deposition and its spatial pattern in main forest ecosystems along north-south transect of eastern China. Chin Geogra Sci 24:137-146

Zhang HM, Forde BG (1998) An Arabidopsis MADS box gene that controls nutrient-induced changes in root architecture. Science 279:407-409

Zhang JB, Cai ZC, Zhu TB, Yang WY, Müller C (2013) Mechanisms for the retention of inorganic $\mathrm{N}$ in acidic forest soils of southern China. Sci Rep 3:2342 